\title{
Anna Igou, Nothing Consumed: The Dangerous Space of Food in Madame Bovary
}

\section{Maria Emanuela Raffi}

\section{(2) OpenEdition}

1 Journals

\section{Edizione digitale}

URL: http://journals.openedition.org/studifrancesi/2229

DOI: $10.4000 /$ studifrancesi.2229

ISSN: 2421-5856

\section{Editore}

Rosenberg \& Sellier

\section{Edizione cartacea}

Data di pubblicazione: 1 aprile 2014

Paginazione: 173

ISSN: 0039-2944

\section{Notizia bibliografica digitale}

Maria Emanuela Raffi, « Anna Igou, Nothing Consumed: The Dangerous Space of Food in Madame Bovary », Studi Francesi [Online], 172 (LVIII | I) | 2014, online dal 01 avril 2014, consultato il 18 septembre 2020. URL : http://journals.openedition.org/studifrancesi/2229 ; DOI : https://doi.org/10.4000/ studifrancesi.2229

Questo documento è stato generato automaticamente il 18 settembre 2020.

\section{(c) 9 (i) $\Theta$}

Studi Francesi è distribuita con Licenza Creative Commons Attribuzione - Non commerciale - Non opere derivate 4.0 Internazionale. 


\title{
Anna Igou, Nothing Consumed: The Dangerous Space of Food in Madame Bovary
}

\author{
Maria Emanuela Raffi
}

\section{NOTIZIA}

ANNA IGou, Nothing Consumed: The Dangerous Space of Food in Madame Bovary, «French Forum», 38, 1-2, Winter/Spring 2013, pp. 35-50.

1 Il ruolo di consumatrice di Mme Bovary è stato quasi sempre limitato dalla critica ai suoi 'consumi' come lettrice. Anna Igou prende invece in considerazione, nel suo studio, il rapporto con il cibo vero e proprio, analizzando lo spazio che Flaubert gli attribuisce nel romanzo come una specie di «microcosm of the work itself». Nonostante la celebre affermazione di Jean-Pierre Richard ( On mange beaucoup dans les romans de Flaubert»), Emma mangia pochissimo e si concentra sul gesto piuttosto che sul cibo, anche perché il cibo descritto da Flaubert non è fatto per nutrire, ma si rivela essere sempre una costruzione incommestibile, il frutto di un artificio estetico. Come mostra la complicatissima e celeberrima torta nuziale, «little work of art», destinata a organizzare esteticamente uno spazio più che a essere consumata. Tuttavia l'insoddisfatta inappetenza dell'eroina flaubertiana non sembra essere solo il frutto dell'insoddisfacente matrimonio con Charles; l'A. stabilisce infatti una relazione fra l'immangiabile torta nuziale e l'appetitoso castello di La Vaubyessard, dove tuttavia l'unico a mangiare - e non senza conseguenze - è il vecchio e cadente suocero del marchese che "avait dévoré sa fortune et effrayé toute sa famille». Il cibo si rivela dunque nel romanzo flaubertiano come un pericolo (il veleno finale) e ancora prima come un vuoto e il segno di un'assenza di materia o della sua consumazione. 